\title{
Chapter 2 \\ Discards in the Common Fisheries Policy: The Evolution of the Policy
}

\author{
Lisa Borges and Ernesto Penas Lado
}

\begin{abstract}
This chapter deals with the development of the European Union (EU) discard policy over time. It describes the process from 1992, when the issue of discards was first recognised in the Common Fisheries Policy (CFP) reform process, to the Landing Obligation (LO) adopted in 2013. It analyses the context to which policy choices were made that shaped the present format of the EU LO, how it is being implemented and the impact it is having on associated fisheries management measures. Finally, future possible policy developments are examined.
\end{abstract}

Keywords de minimis and high survival exemptions · Discards · European Commission · Landing Obligation

\subsection{Introduction: Historical Background}

\subsubsection{Discards in the Common Fishery Policy}

Discarding of fish has always taken place in European fisheries and has continued since the inception of the Common Fisheries Policy (CFP). Although data are incomplete, the levels of discards in some fisheries have been well known for several decades (CEC 1992).

Traditionally, discards are driven by economic reasons: for many species and sizes there is a limited market acceptability, they have no or low commercial value,

Disclaimer: The views and opinions expressed in this chapter are those of the authors and do not reflect the official position of any employer

\author{
L. Borges $(\square)$ \\ FishFix, Brussels, Belgium \\ e-mail: info@fishfix.eu \\ E. Penas Lado \\ Fisheries Biologist/Manager, Brussels, Belgium
}

(C) The Author(s) 2019

S. S. Uhlmann et al. (eds.), The European Landing Obligation,

https://doi.org/10.1007/978-3-030-03308-8_2 
but also, in a system of limited landings by stock, fishers have traditionally discarded the smaller, lower-value fish to maximise the value of the fish landed and counted against quotas, a practice known as 'highgrading'. However, some rules of the CFP have also traditionally contributed to discarding: certain provisions of the CFP made discarding compulsory, namely for (a) catches over quota, (b) catches of undersized fish and (c) catches not corresponding to the expected catch composition of the legal mesh size (Council Regulation (EC) No 850/98; EC 1998).

The consideration of discarding as a problem for the Common Fisheries Policy was recognised many years ago. As early as 1992, at the time of the first reform of the CFP, the European Commission raised the need to address and resolve this problem in its communication on reform (CEC 1992). However, the question was not seen as a significant problem by the Council of Ministers, and no specific action followed.

In the 2002 reform, discards were also raised as an issue (CEC 2001). However, no specific proposals were made in that regard because the debate following the 2001 communication revealed that discards were not seen as a significant problem, and policy makers focused on other priorities, such as stakeholder consultation, long-term management plans and vessel construction subsidies. Discards were seen, in that context, as an inevitable result of the economic activity and partially a result of the management system, which few seriously questioned at the time.

\subsubsection{The Communications of 2007 and 2011}

The perceptions toward discarding started to change in the mid-2000s. A report from the EU Scientific, Technical and Economic Committee for Fisheries (STECF) in 2006 illustrated the magnitude of the discard problem in EU fisheries (STECF 2006). Following this report in 2007, the European Commission made a first attempt to address the issue systematically in policy terms, through a communication (CEC 2007). But this had little impact: the only result was the introduction of a ban on 'highgrading' in all areas in 2010. This ban was poorly enforced and its effect on the real level of discards was never evaluated.

By 2010 the problem of discarding was being increasingly referred to in the European media and this influenced European public opinion which started to put the EU under pressure to tackle the issue (Borges 2015). Pressure was particularly important in the United Kingdom, where the high levels of discards were used to criticise the CFP and, by extension, the European Union. The compulsory collection of discard data from 2003 as part of the EU Data Collection Framework (DCF), and the publication of some of these data in the mid-2000s contributed to raise awareness by showing the high level of discarding in many EU fisheries. The question of discarding started to be a significant source of embarrassment for the fisheries policy and, by extension, for the European Union.

In 2011 the European Commission published a second communication proposing to set up a process to resolve the problem gradually through cooperation with the 
fishing industry. However, this communication did not bring a real change in policy. It has been suggested that the main reason for this was a lack of incentive for the main players (the industry and Member State administrations) to engage. This, in turn, was considered to be due to the fishing industry believing that there would be no advantage in reducing discards (Penas Lado 2016), coupled with a general perception by most that it was too technically difficult to implement (Fitzpatrick et al. 2011). Finally, it was believed that the absence of a legally-binding common approach would result in a piecemeal approach that would not provide a level playing field for different fleets.

However, this experience was very important to shape the future policy. In a policy characterised by top-down prescriptive approaches, only very few took seriously an alternative, bottom-up, cooperative approach. This was also the lesson learnt by non-EU countries that had previously implemented a non-discard policy, such as Norway (Karp et al., this volume). This eventually led to the consideration by the European Commission that a non-discard policy could only be established through top-down legislation.

\subsection{The Landing Obligation and the CFP Reform of 2013}

\subsubsection{Why a Ban on Discards? The Proposal by the European Commission}

The question of discarding was one of the most prominent issues in the reform of the CFP in 2013. Why? It is interesting to note that the Commission's 'Green paper' on CFP reform, published in 2009 (CEC 2009) did not even consider discarding as one of the five structural deficiencies of the policy. The Commission viewed discarding as an undesirable, but largely inevitable consequence of a management system based on individual stocks, allocated through fixed shares for each Member State. Together with other provisions, such as catch composition rules under the technical measures regulation (EC 1998), discarding was made compulsory under certain circumstances. Since these policy elements were not being questioned, a ban on discarding was initially considered as not appropriate.

In the public debate following the publication of the Green Paper, several contributions touched upon the issue of discards. But these did not come from the industry which, by and large, did not consider discards as a problem. But for a number of environmental NGOs this was an example of the CFP's inability to resolve its many shortcomings, particularly with regards to ecological impacts. In addition, some British media presented the discarding of good, large fish under the CFP as the ultimate demonstration of the absurdity of the policy, and abundantly used the images of fish being discarded as an argument to discredit the CFP (Borges 2015; Gambarato and Medvedev 2016). 
In a context where fisheries issues were no longer confined to fisheries constituencies, the problem of discarding was becoming a major iconic issue with political consequences that reached beyond fisheries policy itself. This was the fundamental reason why an issue largely ignored in the preparation of the fishery policy reform, went to the top of the agenda almost overnight (Joa 2015).

The Commission understood that the high level of discards seriously undermined the credibility of the policy, over and beyond the objective reasons and difficulties behind the phenomenon. Furthermore, the failure to conceptualize the bottom-up approach proposed in the Communication of 2007 illustrated the need for a new approach to address the problem. Last but not least, the experience from abroad (i.e., Norway), having applied a non-discard policy for years, clearly indicated that for the discard ban to work, it needed to be imposed top-down in law, as the only way to overcome the initial resistance from the industry.

These considerations led the Commission to include in its proposal for the reformed CFP (CEC 2011a) the idea of a phased-in ban on discarding by species. This came about relatively late in the process of preparing the reform proposal, to the extent that the initial Impact Assessment of the reform (CEC 2011b) did not evaluate the effects of such a measure, which had to be incorporated at a later stage.

The Commission was fully aware that imposing a Landing Obligation as a top-down measure in a policy that hitherto had made discarding compulsory under a number of circumstances would present many difficulties and some contradictions. However, it was felt that these difficulties could and should be resolved if all players involved, from administrations to the industry, were jointly forced to make it happen. The failure of the bottom-up approach of 2007 was believed to demonstrate that the practical difficulties could be resolved only if the players were all under legal pressure to deliver the results.

\subsubsection{The Debate with the Council of the EU and the European Parliament}

The EU co-legislators reacted to the proposal with mixed feelings: while all agreed that discards in EU fisheries had to be addressed, several Member States and Members of the European Parliament (MEPs) were critical with the specific proposal. Nobody opposed the principle of eliminating or at least reducing discards, but many disagreed on the level of ambition and on the specific details proposed.

The main issue in the negotiation concerned the level of flexibility to apply to the Landing Obligation. This divided the opinions between Member States in Council and MEPs in Parliament. The positions largely reflected the relative weight of industry versus the society at large in establishing the political positions (see also Fitzpatrick et al., this volume; van Hoof et al., this volume). While those more influenced by industry's positions were in favour of a high level of flexibility in the objectives and specific provisions, those more influenced by other societal 
interests favoured more limited flexibility. In any case, the need for at least some mechanisms for flexibility was recognised by all, notably due to the fact that some discard practices were actually the result of the CFP rules themselves. These mechanisms were included to facilitate implementation in practice.

While it was recognised that discard levels were highly variable between different fisheries and areas, the flexibility mechanisms were the same for all cases. This was the result of the emphasis by the co-legislators to ensure the level playing field, and the difficulty to demonstrate beyond doubt that the different discard levels of different fisheries were inevitable.

\subsubsection{The Flexibility Mechanisms}

The result of the negotiations was the adoption of a series of mechanisms of flexibility as follows: species for which fishing is prohibited, species that have high survival rates after being discarded and catches which fall under the de minimis exemption.

\subsubsection{The de minimis Allowance}

The de minimis allowance was the clearest recognition by the co-legislators, that achieving zero discards in some fisheries would be almost impossible, notably on account of quota allocations and the cost of handling unwanted fish. So certain allowances should be established for well-defined cases.

The most significant point of friction was the maximum level of this allowance to continue discarding at sea, and whether such allowance should be consistent in all fisheries or modulated according to different discard levels and different difficulty levels to reduce discarding.

Regarding the former, the decision taken (a maximum of 5\% after a transitional period starting at $7 \%$ ) corresponded to the political wish to avoid a bad image of the policy: if the allowance was too high, then the policy would 'look' as if current discard levels could in many cases be maintained, and the co-legislators wanted to send a clear political message that current fishing practices should change.

More difficult was the second question. The evidence that different European fisheries have very different levels of discarding (for example in the North Sea discard levels vary between practically zero in pelagic fisheries to nearly $50 \%$ in demersal ones, ICES 2017a) was compounded by the desire of the co-legislators to establish measures that would not look discriminatory. And in the absence of accurate data on different discard levels, providing for different allowance levels for different fisheries could be seen as discriminatory. The CFP's traditional priority to establish a 'level playing field' translated into a de minimis provision with the same ceiling for all fisheries. This was introduced under the expectation that discard plans in certain areas would not need to make full use of the maximum allowance and that 
this maximum allowance would be used only in the most difficult cases. In any case, it was believed by the co-legislators that there should not be, under any circumstance, discard levels higher than the 5\% of the de minimis rule (although a phasingin starting at $7 \%$ was agreed). This was not based on science, but on the political drive to look ambitious: some co-legislators indicated that a tolerance level of two digits would look like nothing would change.

\subsubsection{The High Survival Exemption}

This exemption was an obvious one: there is no point in landing and eventually killing individuals which otherwise would have survived being discarded. Therefore a high survival clause was included to allow discarding of individuals and species that were scientifically demonstrated to be resilient towards capture-and-discarding processes. However, a definition of what threshold level may be considered as "high" was not given.

Some species are known to survive outside seawater for a time, such as molluscs, skates and rays. This may also be true for some crustaceans. It becomes more complex for fish, whose survival after discarding is not well known in many cases, nor how survival is influenced by technical, biological and environmental factors. This complexity resulted in very loose provisions which have ample room for interpretation.

\subsubsection{The Inter-Stock Flexibility}

This flexibility mechanism (up to $9 \%$ of the TAC of a certain stock could be counted against another stock) was established in recognition that under relative stability, the shares of quota allocated to Member States could, in some cases, make it extremely difficult to comply with the Landing Obligation. Co-legislators, however, were very conscious of the risks of this mechanism, and they established two associated conditions: (a) that the stocks from which the catches are attributed to other stocks would be inside safe biological limits - to prevent the mechanism to result in higher catches of weak stocks and (b) that the real catches by species would be recorded, to avoid catch data being misleading.

Catches that are caught in excess of quotas or for which the Member State has no quota, may be deducted from the quota of the target species provided that they: (i) do not exceed $9 \%$ of the quota of the target species and (ii) the stock of the non-target species is within safe biological limits (i.e. $\mathrm{F}<\mathrm{F}_{\text {lim }}$ and $\mathrm{SSB}>\mathrm{B}_{\text {lim }}$ ).

The inter-species quota flexibility (and de minimis) can provide flexibility in the system to better adjust catch compositions to resemble fishing opportunities and increase both ecological and economic sustainability. However, a STECF report (STECF 2013) warns that these provisions could be used to legally increase catches well above desired or intended levels, and that they will require careful consideration if negative and unintended consequences are to be avoided. 


\subsubsection{What to Do with the Unwanted Fish?}

This was also a hotly debated question concerning whether the undersized fish could be sold for direct human consumption.

Some Member States (particularly from the Baltic basin) considered that, once the undersized fish are caught and counted against quota, it was better to give them some value. They expected this value to be low, so that consuming a significant proportion of the quota with low value fish would be sufficient deterrent not to catch too many undersized fish in the first place.

Other Member States (notably from the Mediterranean basin) considered that this possibility would actually 'legalise' the catch of undersized fish and could lead to an increase in the level of their catches, considering that, unlike the Baltic, small fish can fetch very good prices in that region.

To resolve this dilemma, the co-legislators adopted an intermediate solution: undersized fish inevitably caught should be landed and (where relevant) counted against quota, but then sold only for non-human consumption. The idea behind this solution was twofold:

- if the undersized fish was devoid of any sales value, there would be little incentive for fishermen to land it in the first place, and any amount landed would create a disposal problem for port authorities if nobody could buy it. In addition, the image of -even undersized- fish being shoveled away and dumped with benefit to no-one was not considered a good solution in terms of addressing the credibility problem referred to above.

- If the undersized fish were given some value, but not the full value of the market for direct human consumption, there would be a partial incentive to land the fish inevitably caught, but there would still be an incentive to use the quotas to catch fish that could fetch the full price.

These considerations were based on general knowledge, not on any specific study. This compromise is still largely to be tested in practice (see Iñarra et al., this volume).

\subsection{Implementation}

The Landing Obligation introduced in the 2013 CFP in its article 15 (EU 2013) includes four specific exemptions: species for which fishing is prohibited, species that have high survival rates after being discarded, catches which fall under the de minimis exemption, and catches damaged by predators. It should be noted that the interpretation of these exemptions is not always straightforward. This must be taken into account when evaluating the implementation. 


\subsubsection{The Flexibility Mechanisms}

Species with scientific evidence of high survival rates after being discarded can have an exemption from the obligation to be landed. However, the definition of what is 'high' survival is unclear, while STECF (2013) has concluded that defining a single value cannot be scientifically rationalised and therefore assessing proposed exemptions on the basis of high survival need to be considered on a case-by-case basis, taking account of the species and fisheries involved (Rihan et al., this volume).

This provision has been adopted in several fisheries since 2015. In pelagic fisheries, the application of the exemptions for survival (and the de minimis) in some fisheries have provided the flexibility that allowed the industry to formally comply with the Landing Obligation without any significant change in their operations (PELAC 2015; MEDAC 2017).

As for the inter-species quota flexibility, this instrument had not yet been used by April 2017 (Veits 2017).

\subsubsection{Predator-Damaged Fish}

A further exemption to the LO was introduced with the Omnibus regulation (European Union 2015a), where caught fish damaged by predators should be returned to sea. The reason detailed in the regulation was that such catches "can constitute a risk to humans, to pets and to other fish by virtue of pathogens and bacteria which might be transmitted by such predators".

Nevertheless, this exemption was seen as particularly important for Baltic Sea fisheries targeting salmon, due to the increase in the predatory behaviour of seals consuming salmons caught mainly in longlines (Fitzpatrick and Nielsen 2016). This exemption has indeed been applied to salmon fisheries in the Baltic Sea. But there are no safeguards to limit this mechanism to any particular species or area.

\subsubsection{Discard Plans and Minimum Sizes}

\subsubsection{Discard Plans}

With the delay in the agreement of the multispecies, multiannual plans foreseen in the 2013 CFP between European institutions, and under the objective of introducing the LO progressively, several so-called discard plans were, in accordance with the CFP, adopted by the EC between 2014 and 2017 through delegated acts. The discard plans identify the specific fisheries and species entering the LO and applicable exemptions by sea area for a period of 3 years, based on joint recommendations 
by regional Member States groups in consultation with the relevant Advisory Councils.

Although the discard plans were originally planned as an intermediate legislative measure to be substituted gradually by the agreed multiannual management plans in each sea basin, these are now well-established legislative procedures that continue to be adopted and amended regardless of the adoption of a corresponding multiannual plan.

\subsubsection{Reduction of Minimum Sizes}

The 2013 CFP reform introduced specific provisions which allow changing minimum landings/conservation sizes under discard plans and multiannual plans, still under the prevailing aim of ensuring the protection of juveniles of marine organisms. Catches below minimum conservation reference sizes (MCRS, comparable, but not equivalent, to the previously known MLS) have limited use and cannot be sold for human consumption to avoid creating markets for undersized fish.

In the Baltic Sea, the size at which cod can be sold for human consumption was reduced in 2015, i.e. the MLS of $38 \mathrm{~cm}$ changed to a MCRS of $35 \mathrm{~cm}$ (EU 2014a). As expected, there was an increase in cod landings between 35 and $38 \mathrm{~cm}$, which in turn caused an increase in national quota consumption, because the average fish size of Baltic cod stocks is small (MRAG 2016). At the same time, the industry reported difficulty in increasing gear selectivity due to the restrictions in the trawl gear allowed in the Baltic Sea (BSAC 2016; Valentinsson et al., this volume). This resulted in decreased selectivity by incentivizing commercialization of smaller size eastern cod, while there was no apparent reduction in discard rates (ICES 2017a). This ran counter to the idea of the legislators about the need for increasing selectivity in order to facilitate the implementation of the Landing Obligation.

Furthermore, in south western Atlantic waters, anchovy caught in CECAF area 34.1.2 and in ICES subarea 9 also had a reduction in minimum size with the introduction of the LO in 2015, from a MLS of $12 \mathrm{~cm}$ to a MCRS of $9 \mathrm{~cm}$ (EU 2014b). In the Skagerrak and Kattegat in 2016, Nephrops human consumption size was also reduced from $130 \mathrm{~mm}$ total length and $40 \mathrm{~mm}$ carapace length to $105 \mathrm{~mm}$ and $32 \mathrm{~mm}$ respectively (EU 2015b); while clam (Venus spp.) size limits in the Adriatic Sea went from $25 \mathrm{~mm}$ to $22 \mathrm{~mm}$ in 2017 (EU 2016a).

\subsubsection{Additional Regulatory Mechanism: TACs and Prohibited Species}

With the phased introduction of the LO between 2015 and 2019, several other regulatory mechanisms have since been used to deal with the LO. 


\subsubsection{TAC Footnotes}

Historically, the TAC and quota regulations have included footnotes for some pelagic stocks TACs (e.g. horse mackerel) detailing specific percentages ( $2 \%$ or $5 \%$ ) of catches of non-target species (e.g. boarfish, haddock, whiting and mackerel) that can be taken as bycatch in pursuit of that target TAC, without being accounted for in the respective non-target stock but on the target pelagic TAC. However, only in 2018 have the footnotes included the LO provisions on interspecies flexibility and its $9 \%$ maximum combined catch, and more importantly that the non-target stocks be within safe biological limits.

As the catches of non-target stocks are not necessarily accounted for in their respective TACs, there is a risk of overexploitation of those non-target stocks. STECF $(2013,2017 b)$ highlighted that there is the potential to significantly increase the mortality on non-targeted bycatch species to levels inconsistent with achieving $\mathrm{F}_{\mathrm{MSY}}$ to the extent that stock biomass could be reduced below safe biological limits. This underlines the importance of ensuring that the use of flexibility mechanisms needs to be consistent with the achievement of the Maximum Sustainable Yield (MSY) objective of the CFP.

\subsubsection{TAC Increases}

Since 2015, catches by fisheries subject to the phased introduction of the LO (with some exemptions) should have been brought to shore and landed. To accommodate the predicted increase in landed catch from such fisheries, the relevant 2015, 2016 and 2017 TACs were increased in accordance with the estimated catch that formerly would have been discarded (Borges 2018). According to the European Commission (2017a, b), TAC adjustments are part of the overall package of measures to implement the LO but they should nevertheless not jeopardise the $\mathrm{F}_{\mathrm{MSY}}$ objective or increase fishing mortality.

According to Borges (2018), of the 40, 64 and 88 TACs under the LO between 2015 and 2017, respectively, around 30\% (the majority of which being TACs for demersal stocks) were increased in 2016-2017 to account for the LO, and of these, 10 TACs were set already above landings advice before any adjustments were made. Therefore, the author concludes that the LO is likely to have contributed to TAC increases above maximum advised catch in 2016 and particularly in 2017 to accommodate the predicted increase in landed catch, and will continue to do so until 2019 when all EU TAC regulated stocks and fisheries in the Atlantic come under the LO. In addition, the fact that these TAC increases have been allocated according to relative stability limits considerably compromises their ability to resolve choke species situations for Member States having zero quota or very low quotas of the stocks concerned. 


\subsubsection{TACs Suppression}

Removing TACs from annual TAC regulations so that associated stocks are removed from the LO has been put forward by several stakeholders as a way to deal with problematic stocks, i.e. where discarding is high due to low commercial value and/or where quotas are insufficient to cover catches.

In 2017, following a request from the EC, ICES assessed the sustainability risk to the stock of dab and flounder of having no catch limits as low, as long as dab and flounder remains largely bycatch species (ICES 2017b). With this advice, the EC proposed, and Council agreed, to delete the combined TAC for dab and flounder in the North Sea (EC 2017a). With the suppression of the TAC, these two stocks were removed from the LO and no longer constitute a risk for premature closure of the target fisheries for plaice and sole where they are bycaught. However, they continue to be discarded in high numbers, likely to have between $10 \%$ and $30 \%$ survival after discarding and low commercial value, but continue to be caught in fisheries that no longer have the incentive to improve selectivity.

In 2018a, discussion is going on regarding several additional TAC removals (EC 2017b).

\subsubsection{Zero TACs}

Zero TACs have been used for a number of years in cases where specific stocks are considered extremely overexploited and in need of complete protection from fishing. In the TAC 2017 regulation (EU 2017), picked dogfish (spurdog, Squalus acanthias) were listed as a prohibited species. Specimens should therefore not be harmed and if caught should be released immediately, with the exception for vessels operating in a specific area where landings of up to 270 tonnes of dead picked dogfish are allowed, as long as vessels are engaged in a 'bycatch avoidance programme'. Furthermore, any vessel engaged in such a programme may land not more than 2 tonnes per month of picked dogfish that is dead at the moment when the fishing gear is hauled on board.

The listing of spurdog on the prohibited species list, but with a TAC, has initiated a discussion on how to deal with zero TAC species under the LO: in terms of which species should be listed as prohibited, how species are chosen to be on the list, their level of protection and the level of enforcement. NGOs' position is that designating stocks with zero TAC advice as prohibited species will not protect them from overfishing, and provides little incentive for fishers to improve the selectivity of their fishing practices.

Listing a species on the prohibited species list means discarding can continue, and without a post-release high survival, this measure adds little to the sustainability of the stock. 


\subsubsection{Prohibited Species List}

Both the annual TAC and the technical measures regulations include a list of species for which deliberate catching, retention on board, transshipment or landing is prohibited. Furthermore, when caught, specimens should not be harmed and should be promptly released back into the sea. Species listed in the Convention on International Trade in Endangered Species of Wild Fauna and Flora (CITES) Appendix I are included on the prohibited list. However, except for when listed in CITES, no other specific criteria are known for granting inclusion. As stated in the previous section about zero TACs, several species and stocks have been recently added and removed from the list when they pose a specific issue with the implementation of the LO.

According to STECF (2017c), the prohibited species list should ideally only be used for species which are biologically sensitive to any exploitation. Without additional management measures to improve survival, listing a species will not necessarily lead to a decrease in mortality. Furthermore, the decision to include, or remove, any species on or off the list should be made according to transparent criteria developed in a participatory process.

\subsubsection{Technical Measures}

Technical measures at EU level are specified through several regulations dating back to 1998 , when the original technical measures regulation was adopted (Council Regulation (EC) No 850/98). This regulation specifies areas and seasons where fishing is prohibited, prohibited fishing methods, minimum landing sizes, minimum mesh sizes, among many other measures to minimise the impact of fishing on the marine environment.

In light of the reformed CFP, to simplify rules, and to allow for the introduction of new mechanisms to increase selectivity to facilitate the Landing Obligation, the EC has proposed a new framework for technical conservation measures (EC 2016a). At the time of writing, this proposal was still being discussed by the EU co-legislators.

\subsubsection{Multiannual Management Plans}

There have also been indirect effects of the LO in other fisheries management measures. The argument that the reality of mixed fisheries associated with the LO is incompatible with reaching MSY for all stocks simultaneously has been gaining momentum in Europe and has been addressed inter alia by Sissenwine et al. (2014) and in the EU research project MYFISH (Rindorf et al. 2017). The discussion concerns different maximum allowed MSY catch opportunities, associated with 
premature closure of mixed fisheries under the LO, and under- or over-utilization of some of those catch opportunities.

\subsubsection{1 $\quad F_{\text {MSY }}$ Upper Range}

The management plans in the reformed CFP have no explicit harvest control rules (HCRs) but include $\mathrm{F}_{\mathrm{MSY}}$ ranges between which fishing opportunities can be set when pre-determined conditions are met (EC 2016b; EU 2016b).

The use of the $\mathrm{F}_{\mathrm{MSY}}$ upper range has been justified to allow for mixed fisheries to adapt to the LO. Managers argued that extra flexibility is needed to cope with the LO and avoid premature fisheries closures, while NGOs defend that the objective of "above MSY levels" enshrined in the CFP is not in line with any F value above $\mathrm{F}_{\mathrm{MSY}}$.

Actually, the case for a flexible consideration of $F_{M S Y}$ values is based on various arguments: from the need to address choke species problems to the multi-objective nature of the legal basis of the policy both in the EU Treaty and in international fisheries law.

This question has been resolved in the framework of the two first management plans adopted after the reform: the plans for the Baltic (EC 2016b) and the plan for demersal stocks in the North Sea (EU 2018). In both cases, the implementation of $\mathrm{F}_{\mathrm{MSY}}$ as a range was consolidated, albeit under certain conditions: that the upper limit be precautionary and that the upper part be used only when SSB is above certain thresholds.

It is too soon to evaluate the results of these conditions, whether they will provide the necessary flexibility to address choke species issues (at the level of the TAC) or whether the conditions associated will limit this flexibility to a very low number of cases.

\subsubsection{Target and Bycatch Species}

The new multiannual management plan for the North Sea basin (EU 2018) considers species: (a) that should be managed through MSY ( $\mathrm{F}_{\text {MSY }}$ by 2020) (b) species that may be managed by precautionary approach if MSY advice is not available and (c) other species not subject to catch limits to be managed according to the precautionary approach.

Although the Landing Obligation must apply to all stocks under TAC management, regardless of whether they are target or bycatch stocks, this classification has implications for the implementation of the policy: the classification of the stocks concerned as 'target' or 'bycatch' stocks seems to respond, at least to some extent, to their consideration as 'choke' species, so this would seem to be a case where the implementation of the Landing Obligation has implications for the approach towards MSY objectives. 


\subsubsection{Monitoring, Control and Enforcement}

Monitoring and enforcement are essential parts of the implementation of the Landing Obligation. Not only the credibility of the policy depends on effective enforcement, but also its expected positive effects will only be realised if adequate monitoring takes place. For example, the improvement of data (due to reporting on everything that is removed from the sea) is an expected side benefit of the Landing Obligation, but only if effective monitoring takes place. On the other hand, the flexibility mechanisms available will only be used to the full extent if the industry feels the pressure of enforcement; otherwise there would be little incentive to use such mechanisms, which would in turn give the impression that the whole policy is inapplicable.

The move to managing catches instead of landings requires new forms of monitoring (James et al., this volume; Nuevo et al., this volume) and it is partly through this monitoring that the incentive for compliance with the LO and the motivation to avoid unwanted catches can be generated (see also Kraak and Hart, this volume).

\subsubsection{Postponement of Serious Infringement}

Failing to comply with the Landing Obligation is categorized as a serious infringement under the control regulation (Regulation (EC) No. 1224/2009; EC 2009), but a 2 year delay was agreed in the so-called Omnibus regulation in 2015. Sanctions only took effect from the January 1st, 2017 (EU 2015a); from this date MSs had to start applying the points system for illegal discarding.

Although the omnibus regulation did not delay the enforcement and control of the LO, MSs have taken a soft approach in these two first years of the introduction of the LO and have focused on information sharing and training activities rather than on LO compliance (STECF 2017a).

\subsubsection{Reporting on the Implementation of the LO}

The Omnibus regulation (EU 2015a) introduced the obligation to the EC to submit an annual report, starting in 2016 until 2020, on the implementation of the Landing Obligation. This report should be based on information given by the Member States, the Advisory Councils and other relevant sources.

The 2015, 2016 and 2017 MSs reports were reviewed and summarised by STECF (2016, 2017a, 2018) and show a qualitative analysis of the efforts made by MSs on the different areas of the LO implementation (Rihan et al., this volume). Nevertheless, in 2017 STECF noticed that, "overall, Member States indicate that difficulties encountered so far have been minimal but several reports have highlighted that the most significant issue they face is the industries' reluctance to implement the 
Landing Obligation, despite considerable efforts to disseminate information to them. They also report that fishers seem slow to change fishing practices; and in many areas, a "business as usual" mentality seems to prevail".

\subsubsection{Revision of the Control Regulation}

EC is proposing a revision of the Control Regulation (EC) No. 1224/2009 (EC 2009) with a draft proposal adopted in 2018 (EC 2018b). The EC has started a discussion on the elements of this review, and have stated their intention to include the use of Remote Electronic Monitoring (REM or EM, video and sensors system; James et al., this volume) to monitor the implementation of the $\mathrm{LO}$ on selected fisheries on a voluntary basis (EC 2017b).

In this context, and in a letter inviting inputs from Advisory Councils on its proposal for establishing Specific Control and Inspection Programmes, the EC stated that "independent research, audits of the MS control systems conducted by the Commission, and the 'last-haul' (Nuevo et al., this volume) and other project initiatives driven by the European Fisheries Control Agency (EFCA) alongside the MS authorities, all indicate a general lack of compliance with the LO and that illegal and unrecorded discarding is widespread".

\subsection{Future Perspectives}

At this point in time it is difficult to foresee future developments. The effects of the Landing Obligation as established cannot be assessed ex ante because these effects depend largely on whether Member States will use existing flexibility mechanisms to the full. It also depends on the level of enforcement. However, the ongoing experience in the search for practical solutions for implementation allows certain initial conclusions to be drawn.

\subsubsection{Facilitating Implementation}

The effective implementation of this policy as of 2019 will require progress in a number of areas of the policy. Possible ideas are, inter alia:

- Strengthening of at-sea Monitoring, Control and Surveillance (MCS) systems to allow for a level playing field between fisheries and Member States. Already new technologies are being considered and made possible in the revised Control regulation to allow for this.

- Using the flexibility mechanisms to the full. This is not yet the case, in particular with the inter-species cross-reporting mechanism, barely used so far; 
- Consolidating fishing mortality ranges within new multiannual plans. These ranges were first introduced in the Baltic management plan (EU 2016b) largely due to avoiding choke species effects, but have been seriously questioned by environmental NGOs and subject to strict conditions by policy makers;

- Enhancing quota swaps through increasing transparency, providing the European industry with a better knowledge of the swapping opportunities available in other member States;

- Introducing bycatch quotas for stocks where some Member States have zero quotas and where they cannot manage to obtain small quotas through swaps. Although this option may be seen by many as a breach of relative stability, the annual fishing opportunities regulation already contain a number of such bycatch quotas;

- Supporting the establishment of real-time closures, at least in certain fisheries with high proportions of juvenile fish. A legal basis for this already exists in the control regulation (EC 2009);

- Facilitating (through funding of the European Maritime and Fisheries Fund EMFF; EU 2014c) the investment in more selective gear, and in land-based equipment to store and process unwanted catches. At present, very little investment of this kind is taking place.

These ideas may be necessary in different combinations in different areas/fisheries, and the EC has taken the initiative to discuss them with Advisory Councils and Member States' regional groupings to identify the most serious cases and the mechanisms to resolve choke species issues.

\subsubsection{Possible Legislative Changes?}

The European Commission has no plan to propose an amendment to the existing legislation. This indicates that the European Commission believes that it is necessary to try to implement the 2013 policy, and has started a proactive campaign to discuss and promote a variety of ideas to allow for its efficient implementation. The reason is clear: before thinking about a legislative change, it is necessary to use all the elements of flexibility and effective MCS systems to allow for effective implementation.

For the future, the Commission must submit a report on the application of the policy by 31 December 2022. Although it is premature to prejudge what the Commission will decide to report on the Landing Obligation, one can, already at this stage, suggest some ideas to consider regarding a future policy:

- The modulation of objectives. The current legislation provides for exactly the same levels of discard allowances in all areas and all fisheries, thus ignoring very different current levels of discarding and very different levels of difficulty to achieve to those target levels. In the North Sea alone, discard levels in different 
fisheries range from $1 \%$ to $2 \%$ to around $50 \%$ (ICES 2017a). This harmonisation may need to be revised to fix more achievable objectives for different fisheries;

- Establishing clearer objectives for the improvement of selectivity in the context of technical measures. While the 5\% above mentioned may be too simplistic and poorly adapted to different circumstances, the legislation could at least establish as a principle the improvement of exploitation patterns to levels that would maximize MSY yields and minimize the catch of juvenile fish. These principles would then translate into different objectives in different fisheries and areas.

- Advancing towards multispecies approaches would also help reduce choke species effects. The scientific basis for this is being developed, at least for certain areas such as the North Sea (ICES 2013). This could allow a new policy focus where greater flexibility for individual stocks would be compensated with more emphasis on the total removals from the fishery (and thus a more ecosystembased management). Allocation-related chokes would also benefit from a new approach to implement relative stability: more focused on the total bonus that Member States would obtain from the fishery, and less on individual stock allocations; this could be done based on an overall evaluation of the value of fishing rights by Member States and a redistribution of individual quotas within that overall value.

- A new approach to the implementation of relative stability would help address the problem of allocation-related chokes. Indeed, relative stability was established in 1983 as a principle, with the specific allocation keys being open to adaptive revision (EEC 1983). The possibility to include bycatch quotas (already existing in some TACs) would be a solution in some cases. A more ambitious approach would be to recast relative stability as a total percentage of the value that each Member State would obtain from the EU, and then allow for a reallocation of national allocations within these overall percentages, to better match fishing rights with real catches.

In any case, there seems to be no way back from the non-discard policy. The evolution of fisheries policy around the world is going in that direction (Karp et al., this volume), and the practice of discarding is increasingly considered unacceptable from different points of view, including considerations about food security. Any possible future change in the policy is likely to be about adjustments to improve practical implementation and mitigate possible negative results, but a CFP with high levels of discarding will never return.

Acknowledgements Part of this work has received funding from the Horizon 2020 Programme under grant agreement DiscardLess number 633680. This support is gratefully acknowledged.

\section{References}

Borges, L. (2015). The evolution of a discard policy in Europe, Fish and Fisheries, 16 (3), 534-540. https://doi.org/10.1111/faf.12062. 
Borges, L. (2016, February 26). One year on: The landing obligation in Europe. ICES Newsletter.

Borges, L. (2018). Setting of total allowable catches in the 2013 EU common fisheries policy reform: Possible impacts. Marine Policy, 91, 97-103.

Borges, L., Cocas, L., Nielsen, K.N. (2016). Discard ban and balanced harvest: A contradiction? ICES Journal of Marine Science, 73 (6), 1632-1639. https://doi.org/10.1093/icesjms/fsw065.

BSAC. (2016). Joint Working Group (Demersal + Pelagic) to continue the discussions on technical measures for the Baltic and draft amendments to the technical measures regulation for the Baltic 2187/2005. 26-27 January 2016. Gdynia, Poland, p. 12.

CEC. (1992). Report from the Commission to the Council on the discarding of fish in Community fisheries: Causes, impact, solutions. SEC (92) 423 final, 12 March 1992. Brussels, p. 54.

CEC. (2001). Green paper on the future of the common fisheries policy. COM (2001) 135 final, 20 March 2001. Brussels, p. 40.

CEC. (2007). Communication from the Commission to the Council and the European Parliament: A policy to reduce unwanted by-catches and eliminate discards in European fisheries. COM(2007) 136 final, p. 8.

CEC. (2009). Commission of the European Communities Green Paper - Reform of the Common Fisheries Policy. COM (2009)163 final, p. 28.

CEC. (2011a). Communication from the Commission to the European Parliament, the Council, the European Economic and Social Committee and the Committee of the Regions. Reform of the Common Fisheries Policy. COM(2011) 417 final, 13 July 2011. Brussels, p. 12.

CEC. (2011b). Commission Staff Working Paper: Impact Assessment Accompanying the document "Commission proposal for a Regulation of the European Parliament and of the Council on the Common Fisheries Policy". SEC(2011) 891 final.

EC. (1998). Council Regulation (EC) No 850/98 of 30 March 1998 for the conservation of fishery resources through technical measures for the protection of juveniles of marine organisms. Official Journal of the European Union, L125, 1-55.

EC. (2009). Council Regulation (EC) No 1224/2009 of 20 November 2009 establishing a Community control system for ensuring compliance with the rules of the common fisheries policy, amending Regulations (EC) No 847/96, (EC) No 2371/2002, (EC) No 811/2004, (EC) No 768/2005, (EC) No 2115/2005, (EC) No 2166/2005, (EC) No 388/2006, (EC) No 509/2007, (EC) No 676/2007, (EC) No 1098/2007, (EC) No 1300/2008, (EC) No 1342/2008 and repealing Regulations (EEC) No 2847/93, (EC) No 1627/94 and (EC) No 1966/2006. Official Journal of the European Union, L343, 1-50.

EC. (2016a). Proposal for a Regulation of the European Parliament and of the Council on the conservation of fishery resources and the protection of marine ecosystems through technical measures, amending Council Regulations (EC) No 1967/2006, (EC) No 1098/2007, (EC) No $1224 / 2009$ and Regulations (EU) No 1343/2011 and (EU) No 1380/2013 of the European Parliament and of the Council, and repealing Council Regulations (EC) No 894/97, (EC) No 850/98, (EC) No 2549/2000, (EC) No 254/2002, (EC) No 812/2004 and (EC) No 2187/2005. COM (2016) 134 final, 11 March 2016. Brussels, p. 44.

EC. (2016b). Proposal for a Regulation of the European Parliament and of the Council on establishing a multi-annual plan for demersal stocks in the North Sea and the fisheries exploiting those stocks and repealing Council Regulation (EC) 676/2007 and Council Regulation (EC) 1342/2008. COM(2016) 492 final, p. 23.

EC. (2017a). Communication from the Commission on the State of Play of the Common Fisheries Policy and Consultation on the Fishing Opportunities for 2018. COM (2017) 368 final. http:// eur-lex.europa.eu/legal-content/EN/TXT/PDF/?uri=CELEX:52017DC0368\&from=EN. Accessed 29 Aug 2018.

EC. (2017b). Landing Obligation seminar November 2017 - Summary. https://ec.europa.eu/fisher ies/sites/fisheries/files/docs/pages/landing-obligation-seminar-november-2017-summary_en. pdf. Accessed 29 Aug 2018

EC. (2018a). Discarding and the Landing Obligation. https://ec.europa.eu/fisheries/cfp/fishing rules/discards_en. Accessed 29 Aug 2018. 
EC. (2018b). Proposal for a Regulation of the European Parliament and of the Council amending Council Regulation (EC) No 1224/2009, and amending Council Regulations (EC) No 768/2005, (EC) No 1967/2006, (EC) No 1005/2008, and Regulation (EU) No 2016/1139 of the European Parliament and of the Council as regards fisheries control. COM(2018) 368 final, 30 May 2018. Brussels, p. 91.

EEC. (1983). Council Regulation (EEC) No 170/83 of 25 January 1983 establishing a Community system for the conservation and management of fishery resources. Official Journal of the European Communities, L24, 1-13.

EU. (2013). Regulation (EU) No 1380/2013 of the European Parliament and of the Council of 11 December 2013 on the Common Fisheries Policy. Brussels, Belgium. http://eur-lex.europa. eu/LexUriServ/LexUriServ.do?uri=OJ:L:2013:354:0022:0061:EN:PDF. Accessed 29 Aug 2018.

EU. (2014a). Commission Delegated Regulation (EU) No 1396/2014 of 20 October 2014 establishing a discard plan in the Baltic Sea. Official Journal of the European Union, L370, $40-41$.

EU. (2014b). Commission Delegated Regulation (EU) No 1394/2014 of 20 October 2014 establishing a discard plan for certain pelagic fisheries in south-western waters. Official Journal of the European Union, L370, 31-34.

EU. (2014c). Regulation (EU) No 508/2014 of the European Parliament and of the Council of 15 May 2014 on the European Maritime and Fisheries Fund and repealing Council Regulations (EC) No 2328/2003, (EC) No 861/2006, (EC) No 1198/2006 and (EC) No 791/2007 and Regulation (EU) No 1255/2011 of the European Parliament and of the Council. Official Journal of the European Union, L149, 1-66.

EU. (2015a). Regulation (EU) 2015/812 of the European Parliament and of the Council of 20 May 2015 amending Council Regulations (EC) No 850/98, (EC) No 2187/2005, (EC) No 1967/2006, (EC) No 1098/2007, (EC) No 254/2002, (EC) No 2347/2002 and (EC) No 1224/2009, and Regulations (EU) No 1379/2013 and (EU) No 1380/2013 of the European Parliament and of the Council, as regards the Landing Obligation, and repealing Council Regulation (EC) No 1434/ 98. Official Journal of the European Communities, L133, 1-20.

EU. (2015b). Commission Delegated Regulation (EU) No 2015/2440 of 22 October 2015 establishing a discard plan for certain demersal fisheries in the North Sea and in Union waters of ICES Division IIa. Official Journal of the European Union, L336, 42-48.

EU. (2016a). Commission Delegated Regulation (EU) No 2016/2376 of 13 October 2016 establishing a discard plan for mollusc bivalve Venus spp. in the Italian territorial waters. Official Journal of the European Union, L352, 48-49.

EU. (2016b). Regulation (EU) No 2016/1139 of the European Parliament and of the Council of 6 July 2016 establishing a multiannual plan for the stocks of cod, herring and sprat in the Baltic Sea and the fisheries exploiting those stocks, amending Council Regulation (EC) No 2187/2005 and repealing Council Regulation (EC) No 1098/2007. Official Journal of the European Union, L191, 1-15.

EU. (2017). Regulation (EU) 2017/127 of the Council of 20 January 2017 fixing for 2017 the fishing opportunities for certain fish stocks and groups of fish stocks, applicable in Union waters and, for Union vessels, in certain non-Union waters. Official Journal of the European Union, L24, 1-172.

EU. (2018). Regulation (EU) No 2018/973 of the European Parliament and of the Council of 4 July 2018 establishing a multiannual plan for demersal stocks in the North Sea and the fisheries exploiting those stocks, specifying details of the implementation of the Landing obligation in the North Sea and repealing Council Regulations (EC) No 676/2007 and (EC) No 1342/2008. Official Journal of the European Union, L179, 1-13.

Fitzpatrick, M., Graham, N., Rihan, D.J., Reid, D.G. (2011). The burden of proof in co-management and results-based management: The elephant on the deck! ICES Journal of Marine Science, 68(8), 1656-1662.

Fitzpatrick, M., \& Nielsen, K.N. (2016). DiscardLess Policy Brief No1: Year 1 of the Landing Obligation, key issues from the Baltic and Pelagic fisheries, 30 September 2016. https://doi.org/ 10.5281/zenodo.215155. 
Fitzpatrick, M., Frangoudes, K., Fauconnet, L., Quetglas, A. (this volume). Fishing industry perspectives on the EU Landing Obligation. In S.S. Uhlmann, C. Ulrich, S.J. Kennelly (Eds.), The European Landing Obligation - Reducing discards in complex, multi-species and multijurisdictional fisheries. Cham: Springer.

Gambarato, R.P., \& Medvedev, S.A. (2016). Transmedia storytelling impact on government policy change. In Politics, protest, and empowerment in digital spaces (pp. 31-51). Hershey: IGI Global. https://doi.org/10.4018/978-1-5225-1862-4.ch003.

ICES. (2013). North Sea. Multispecies considerations for North Sea stocks. ICES Advice 2013, 6.3.1, p. 9. http://www.ices.dk/sites/pub/Publication\%20Reports/Advice/2013/2013/mult-NS. pdf. Accessed 29 Aug 2018.

ICES. (2017a). Greater North Sea Ecoregion - Fisheries overview. Published 4 July 2017. https:// doi.org/10.17895/ICES/pub.3116.

ICES. (2017b). EU request on a combined dab and flounder TAC and potential management measures besides catch limits. ICES Advice 2017. ICES Special Request Advice, p. 8. http:// ices.dk/sites/pub/Publication\%20Reports/Advice/2017/Special_requests/eu.2017.04.pdf. Accessed 29 Aug 2018.

Iñarra, B., Bald, C., Cebrián, M., Antelo, L.T., Franco-Uría, A., Vázquez, J.A., Pérez-Martín, R., Zufía, J. (this volume). What to do with unwanted catches: Valorisation options and selection strategies. In S.S. Uhlmann, C. Ulrich, S.J. Kennelly (Eds.), The European Landing ObligationReducing discards in complex, multi-species multi-juridictional fisheries. Cham: Springer.

James, K.M., Campbell, N., Viðarsson, J.R., Vilas, C., Plet-Hansen, K.S., Borges, L., et al. (this volume). Tools and technologies for the monitoring, control and surveillance of unwanted catches. In S.S. Uhlmann, C. Ulrich, S.J. Kennelly (Eds.), The European Landing Obligation Reducing discards in complex, multi-species and multi-jurisdictional fisheries. Cham: Springer.

Joa, A. (2015). Fish fight in Europe: A process-analysis of the campaign for a discard ban provision in the EU's CFP Reform. BSc thesis. University of Twente, The Netherlands, p. 54.

Karp, W.A., Breen, M., Borges, L., Fitzpatrick, M., Kennelly, S.J., Kolding, J., et al. (this volume). Strategies used throughout the world to manage fisheries discards - Lessons for implementation of the EU Landing Obligation. In S.S. Uhlmann, C. Ulrich, S.J. Kennelly (Eds.), The European Landing Obligation - Reducing discards in complex, multi-species and multi-jurisdictional fisheries. Cham: Springer.

Kraak, S.B.M., \& Hart, P.J.B. (this volume). Creating a breeding ground for compliance and honest reporting under the Landing Obligation: Insights from behavioural science. In S.S. Uhlmann, C. Ulrich, S.J. Kennelly (Eds.), The European Landing Obligation - Reducing discards in complex, multi-species and multi-jurisdictional fisheries. Cham: Springer.

MRAG. (2016). 4th Surveillance report, DFPO Denmark Eastern Baltic Cod Fishery (p. 28). https:// www.msc.org/track-a-fishery/fisheries-in-the-program/certified/north-east-atlantic/DenmarkEastern-Baltic-cod/assessment-downloads-1/20160128_SR_COD140.pdf

MEDAC. (2017). Annual report on the implementation of the LO for small pelagics. MEDAC Contribution. Ref.: 38/2017, p. 7.

Nuevo, M., Morgado, C., Sala, A. (this volume). Monitoring the implementation of the Landing Obligation: Last Haul programme. In S.S. Uhlmann, C. Ulrich, S.J. Kennelly (Eds.), The European Landing Obligation - Reducing discards in complex, multi-species and multijurisdictional fisheries. Cham: Springer.

PELAC. (2015). Annex II: Experiences with the Landing Obligation in pelagic fisheries (pp. 9-12). http://www.pelagicac.org/media/pdf/1516PAC12\%20Recommendations\%20n\%20control\% 20of\%20LO.pdf

Penas Lado, E. (2016). The common fisheries policy. The quest for sustainability (p. 395). Ames: Wiley Blackwell.

Rihan, D., Uhlmann, S.S., Ulrich, C., Breen, M., Catchpole, T. (this volume). Requirements for documentation, data collection and scientific evaluations. In In S.S. Uhlmann, C. Ulrich, S.J. Kennelly (Eds.), The European Landing Obligation - Reducing discards in complex, multi-species and multi-jurisdictional fisheries. Cham: Springer. 
Rindorf, A., Dichmont, C.M., Thorson, J., Charles, A., Clausen, L.W., Degnbol, P., et al. (2017). Inclusion of ecological, economic, social, and institutional considerations when setting targets and limits for multispecies fisheries. ICES Journal of Marine Science, 74(2), 453-463.

Sissenwine, M.M., Mace, P., Lassen, H.J. (2014). Preventing overfishing: Evolving approaches and emerging challenges. ICES Journal of Marine Science, 71(2), 153-156.

STECF. (2006). Discards from community vessels. STECF Plenary meeting, Ispra, 6-10 November 2006. Publications Office of the European Union, Luxembourg. https://stecf.jrc.ec.europa.eu/ documents/43805/99464/2006-11_23rd+report+of+the+STECF.pdf. Accessed 29 Aug 2018.

STECF. (2013). Landing Obligation in EU fisheries (STECF-13-23). Publications Office of the European Union, Luxembourg, EUR 26330 EN, JRC 86112, p. 115.

STECF. (2016). Methodology and data requirements for reporting on the Landing Obligation (STECF-16-13). Publications Office of the European Union, Luxembourg, EUR 27758 EN. https://doi.org/10.2788/984496.

STECF. (2017a). 54th Plenary meeting report (PLEN-17-01). Publications Office of the European Union, Luxembourg; EUR 28569 EN. https://doi.org/10.2760/33472.

STECF. (2017b). 55th Plenary meeting report (PLEN-17-02). Publications Office of the European Union, Luxembourg. EUR 28359 EN. https://doi.org/10.2760/53335.

STECF. (2017c). Long-term management of skates and rays (STECF-17-16). Publications Office of the European Union, Luxembourg.

STECF. (2018). 57th Plenary meeting report (PLEN-18-01). Publications Office of the European Union, Luxembourg. ISBN 978-92-79-85804-8. https://doi.org/10.2760/088784.

Valentinsson, D., Ringdahl, K., Storr-Paulsen, M., Madsen, N. (this volume). The Baltic cod trawl fishery: The perfect fishery for a successful implementation of the Landing Obligation? In S.S. Uhlmann, C. Ulrich, S.J. Kennelly (Eds.), The European Landing Obligation - Reducing discards in complex, multi-species and multi-jurisdictional fisheries. Cham: Springer.

van Hoof, L., Kraan, M., Visser, N. M., Avoyan, E., Batsleer, J., Trapman, B. (this volume). Muddying the waters of the Landing Obligation: How multi-level governance structures can obscure policy implementation. In S.S. Uhlmann, C. Ulrich, S.J. Kennelly (Eds.), The European Landing Obligation - Reducing discards in complex, multi-species and multi-jurisdictional fisheries. Cham: Springer.

Veits, V. (2017). Presentation given at the European Parliament Public Hearing on the state of play of the implementation of Landing Obligation and allocation of quotas (24 April 2017). http:// www.europarl.europa.eu/cmsdata/117542/Veronika\%20Veits_DG\%20Mare.pdf. Accessed 29 Aug 2018.

Open Access This chapter is licensed under the terms of the Creative Commons Attribution 4.0 International License (http://creativecommons.org/licenses/by/4.0/), which permits use, sharing, adaptation, distribution and reproduction in any medium or format, as long as you give appropriate credit to the original author(s) and the source, provide a link to the Creative Commons license and indicate if changes were made.

The images or other third party material in this chapter are included in the chapter's Creative Commons license, unless indicated otherwise in a credit line to the material. If material is not included in the chapter's Creative Commons license and your intended use is not permitted by statutory regulation or exceeds the permitted use, you will need to obtain permission directly from the copyright holder.

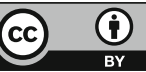

